\title{
Chapter 21 \\ Dilemmas of an Integrated Multi-use \\ Climate Adaptation Project \\ in the Netherlands: The Oekense Beek
}

\author{
Maria Kaufmann and Mark Wiering
}

This case study presents an integrated, collaborative and multi-use climate change adaptation project in the Netherlands: the "Oekense Beek". The aim of this chapter is to illustrate the challenges of such a project in a context where the cooperation with private landowners and users is mainly based on a voluntary approach. Governmental authorities have several policy instruments at their disposal that may help them find "agreements" with private landowners. However, most agreements need to be found on a voluntary base with financial incentives or communicative approaches. Consequently, governmental authorities are confronted with several challenges, such as the lack of urgency and awareness for climate change among stakeholders, the long duration and iterative adjustment of project plans due to an increasing number of involved stakeholders, coordinating multiple land uses, developing innovative synergies and ensuring an equal treatment of land users. These aspects make it difficult to set up and implement an integrated climate change adaptation project.

\section{Introducing the Climate Change Adaptation Project Oekense Beek-An Integrated Approach}

Climate change is often described as a wicked problem (Termeer et al. 2013), which asks for new forms of governance based on the coordinated efforts of various governmental and non-governmental stakeholders from different policy sectors (Olsson et al. 2006; Ansell and Gash 2007; Collins and Ison 2009; Baird et al. 2016). However, the complexities of such integrated and non-hierarchical decision-making processes tend to be underestimated (Wise et al. 2014; Biesbroek et al. 2015; Duit 2015; Sjöst-

\footnotetext{
M. Kaufmann $(\bowtie) \cdot$ M. Wiering

Institute for Management Research, Radboud University Nijmegen, Nijmegen, Netherlands e-mail: m.kaufmann@fm.ru.nl

M. Wiering

e-mail: m.wiering@fm.ru.nl

(C) The Author(s) 2019

T. Hartmann et al. (eds.), Nature-Based Flood Risk Management on Private Land, https://doi.org/10.1007/978-3-030-23842-1_21
} 
edt 2015), particularly in a context where private landowners and users are involved. This case study presents an integrated, collaborative and multi-use climate change adaptation project in the Netherlands. The aim of this chapter is to illustrate the challenges of such a project in a context where the cooperation of private landowners and users is given on a voluntary basis.

The climate change adaptation project "Oekense Beek" is an interesting case as it actively aims for an integrated approach. The project aims to go beyond the traditional distinctions made in water quantity management. It aims to manage floods and droughts in an integrated manner, acknowledging the disparate consequences of climate change, which may increase the intensity of both flood events and dry periods. In this project, the solutions to these issues are found in nature management, for example, recovery of natural hydrological dynamics or improving the quality of the soil to increase the water infiltration capacity. A representative of the province described the vision of the project to connect sectorial approaches. The representatives hope that this project may become a pilot for the East of the Netherlands, where several areas may face similar climate change consequences.

Apart from involving various policy sectors, cooperation with private landowners and users is an essential element for realizing the project as measures have to be implemented on private land. Multiple forms of land-use need to be coordinated. The main landowners in the project area are a nature organisation-Natuurmonumenten - and farmers with crop fields and livestock. The chapter addresses following questions: How do governmental authorities approach private landowners and users? What kinds of instruments have governmental authorities at their disposal to find agreements with private landowners in the context of climate change adaptation? What are the challenges and dilemmas of such an integrated and collaborative climate change adaptation project? At the moment, the project is delayed and remains in the development phase. Due to the difficulties in finding broad support for the project among the local stakeholders, the next steps will be to carefully map the current status and identify what is actually possible to increase climate resilience. Regional authorities think that this will facilitate communication and collaboration among local stakeholders.

\section{Data Collection and Analysis}

Inspired by the literature on governance and policy instruments (Arts et al. 2006; Bemelmans-Videc et al. 2010; Driessen et al. 2012), this chapter focuses on the involved actors, their interests and how they communicate and cooperate within the project. The chapter explores the procedural governance approach and the policy instruments governmental officials have at their disposal to find agreements with private land users or owners: coercive instruments ("sticks"), financial incentives ("carrots") and communicative instrument ("sermons") (see Bemelmans-Videc et al. 2010). The chapter is based on interviews conducted in autumn 2017 with governmental representatives: the current project manager from the regional water authority 
Vallei en Veluwe, the initiator of the project from the province of Gelderland and a telephone interview with a policy maker of the municipality Brummen. Additionally, policy documents and research reports have been analysed. The documents and the transcribed interviews were analysed deductively according to the following criteria: stakeholders and tasks, policy instruments and barriers.

\section{Setting the Scene: Locating the Oekense Beek}

The project is located in the eastern part of the Netherlands in the province of Gelderland. The next small-sized city is Zutphen (47,000 inhabitants in 2017). The project is situated in the transition zone between the Veluwe, a hilly area with forests and sand soil, and the Ijssel, a river. Both the Veluwe and the Ijsseldelta are Natura 2000 areas and part of a larger ecological corridor. The project covers the complete stream Oekense Beek, which rises close to the Veluwe and discharges into the Ijssel, just like the streams: Rhienderense Beek and the Voorstondese Beek. The landscape is very diverse, a result of the country estates of the 14th and 15th century. It is characterised by a mix of small-scale forests, streams, fields and moor (Interviews 2017; Provincie Gelderland 2016).

The Oekense Beek is a straightened and deep stream. The area is strongly drained. Consequently, the groundwater levels are rather low, which lowers the water infiltration capacity of the area and diminishes its buffer function. Consequently, the stream responds very quickly to precipitation events, or the lack thereof. A representative of the regional water authority describes the stream as follows: "When I visited the stream in early spring this year, when it was still raining, the stream was completely filled with water. When I came along in May, the stream lay dry, the same in August. In September, it started to carry a little bit water." With regards to climate change, this may lead to increasing floods in the future as the intensity and frequency of precipitation events is projected to increase. But also droughts are projected to increase in the future (Interview 2017).

To combat these projections, the aim of the project is to increase the buffer capacity of the area so that the increase in precipitation can be compensated. In other words, the sponge function of the stream shall be increased so that an excess of water can be retained during times of intense rainfall discharging it slower and storing it for times of drought. This includes a number of measures that will promote a better infiltration of water in the area and a slower discharge of water so that the water can also be stored for periods of droughts. Measures include for example, the re-naturalisation of the stream by recovering its old meanders with broad shores and pools that can be inundated. These meanders are still visible in the landscape and can be reconnected. Through these measures the groundwater level will be raised. This is also needed to achieve the Natura 2000 objectives in the area, which demand, for example, the development of floodplain vegetation (natte natuur) and alluvial forest. Other climate change adaptation measures include improving the quality of the soil. For example, 
a higher concentration of organic substances in the soil increases the soil's water infiltration capacity (Provincie Gelderland 2012; Stroming 2013; Interviews 2017).

\section{Who Is Who? Mapping the Actor Landscape}

In the Netherlands, the distribution of responsibilities and competencies is quite clearly structured. In the climate adaptation project Oekense Beek, the main actors involved are the province of Gelderland, the regional water authority Vallei en Veluwe, the municipality Brummen, natuurmonumenten and farmers.

\section{The Province of Gelderland: An Integral Organisation}

The province of Gelderland is one of 12 provinces in the Netherlands. Dutch provinces form a regional generic administrative layer between the national government and municipalities. They are responsible for spatial planning. In so-called "structural visions", they designate areas for residential housing, economic purposes, nature development, agricultural activities, recreation, traffic, etc. In other words, they take on an integrated perspective considering various interests. Provinces often take on the role of an area manager cooperating closely with different governmental and non-governmental actors (Kaufmann et al. 2016).

In this project, the province initiated the plan but delegated the preparation, planning and implementation to the regional water authority who took over the role of area manager. This decision was based on two main reasons; firstly, water plays a fundamental role in this project: achieving the objectives asks for fundamental changes in the water system. Secondly, the project asks a lot of contact with local users: natuurmonumenten and farmers. As the regional water authorities traditionally have more contact with these actors, they have more experience with establishing contact with them. Delegating the responsibility for projects is a common practice in the province (Interviews 2017).

The provincial responsible was very active in linking this project up to various funds to make subsidies available for the different measures (see below). As he put it: "I look around in that organization [province] and see where money is available. You tell a nice story so that the different funds could all invest into your project. You can make a nice start with that collected money" (Interview 2017). This indicates that the pro-activeness and networking capabilities of the involved actors are important to develop and finance such an integrated project. 


\section{The Regional Water Authority "Vallei en Veluwe"}

In the Netherlands, regional water authorities (a sector-based layer of regional government, with independent tasks and tasks delegated from the provinces) are democratically elected organisations responsible, among others, for water level management (e.g., operating pumps, or maintaining primary and regional flood defences) (Kaufmann et al. 2016). In this project, Vallei en Veluwe took on, as explained above, the role of the area manager. It is responsible for preparing and implementing the climate change adaptation measures. A representative of the water authority summarized the main interest of the authority as follows: "If we can't guarantee dry feet for the people living in the area, then our administrative board will not cooperate." The regional water authority is the owner and manager of the water course. Vallei en Veluwe divides its regional water courses into different categories: A, B and C. The Oekense Beek is an A-water course, which means the regional water authority is responsible for its management. In contrast, B- and C-water courses are the responsibility of the owner. B-water courses are reviewed twice per year by the regional water authority (Interviews 2017).

In the Netherlands, the regional water authorities used to be very autonomous actors focused on their hydro-engineering expertise to take decisions based on quantitative calculations and models. In the last decades, the organisations have become increasingly integrated, taking into account other values and interests (Kaufmann et al. 2016). How much progress has been made in terms of this developments differs among the 22 regional water authorities. Even though 'Vallei en Veluwe' is described as a relatively integrated organisation, representatives of other governmental organisations also state that there is still room for improvement in terms of increasing the "integral thinking" (Interviews 2017).

As an area manager, the authority is also responsible for approaching the different actors, including private landowners, in this area. When approaching private actors, the representative of the regional water authority takes on an integrated position representing all involved governmental and non-governmental actors, namely the province, municipality Brummen, but also the natuurmonumenten. The representative of the regional water authority is hired by, for example, the municipality to represent their interests. This has the advantage of giving the citizens a clear contact person (Interviews 2017).

\section{The Municipality of Brummen}

In the Netherlands, municipalities are responsible for developing a local land use plan, where they designate particular land-uses (Kaufmann et al. 2016). The designation of plans cannot so easily be changed from, for example, farmland to nature. If the designation is changed, it needs to be compensated. The project takes place in the municipality Brummen. The municipality appears to be enthusiastic and interested in 
the project. It does not take a leading role but is interested in creating a liveable area for its citizens, particularly with regards to recreation. It provides financial means to develop recreational opportunities in the project area (Interviews 2017).

\section{Natuurmonumenten}

Natuurmonumenten is a non-governmental nature conservation organisation, which is above all interested in nature development: natural processes and connectivity between nature areas. Its inclination toward the project is positive and supportive. The NGO owns land in the area, for example, the old country estates Leusveld and Voorstonden. The designation of this land is nature function and partly Natura 2000 areas. Natuurmonumenten started already with implementing measures on their land. They started logging trees to revive the meander (Interviews 2017). Natuurmonumenten leases part of their land to farmers. These are mainly long-term leasehold contracts (erfpachtcontracten) (Provincie Gelderland 2016).

\section{Farmers}

The project illustrates that farmers are by no means a homogeneous group but have heterogeneous interests and approaches. The activities carried out in the project, for example, raising the water level, are, of course, not necessarily beneficial for farming activities. The periods when the soil is wet may increase from two to four months. According to the interviewees, many farmers argue that they need to prioritise running a business and making money, a concern that appears to be taken seriously by the provincial, municipal and water authority representatives. One organic farmer leases land from natuurmonumenten. Even he is not interested in measures at the moment as he wants to keep his livestock outside on the fields, which is not possible when they are too wet. On the other hand, one farmer fundamentally changed course: he sold his livestock and adopted a more sustainable farming practice. He is now nature conservation manager for natuurmonumenten and plants particular types of vegetation. He receives financial payment for delivering these green services. The governmental representatives would like to use his story as an exemplary illustration for other farmers and encourage him to become an ambassador for the area (Interviews 2017). 


\section{Developing an Integrated Cooperation with Governmental and Non-governmental Actors}

The project was initiated by the province of Gelderland. The initial aim was to address the nature development objectives in the context of Natura2000. These objectives included connecting various ecosystems and developing alluvial forest, among others. As the province was also actively involved in the discussions surrounding the Western European Climate Corridor, the project was combined with climate change adaptation initiatives (Interviews 2017).

The province developed a broad "umbrella vision" for the area. Subsequently, it analysed which actors could play a role in this area and discussed internally what could be their interests in the project. Afterwards the province presented their umbrella vision to the other actors to discuss it collectively. In this case, these actors included the regional water authority, the municipality Brummen, natuurmonumenten, and LTO. In these discussions, the province tried not to take a dominant or authoritarian position but aimed to have an open deliberation. Several interviewees pointed out that emphasizing the interests of different parties is very important in such a project. As one provincial respondent described his approach, "You get together and say: We have this broad idea. What do you think about it? What are your interests? Where do you see problem? How could we address your problems so that we can cooperate in this project?" The main actors-meaning the province, regional water authority, municipality Brummen, natuurmonumenten - agreed on the aim of the project in terms of climate change adaptation and nature development. Together, they deliberated about potential measures and strategies (Interviews 2017).

As these objectives asked for fundamental changes in the water system, several hydrological studies were conducted to model the surface water and the groundwater of the area to get a good picture of the water system. These models considered also various climate change scenarios. Additionally, geological and soil characteristics were analysed. Scientific experts and analysts as well as the governmental authorities come together in expert meetings and combine the different maps to explore which measures are actually feasible. This process is still in progress. A representative of the regional water authority mentioned that it is important to know the range of possible measures and actions. Otherwise, it is difficult to go into negotiations with private stakeholders because the governmental representatives do not know whether they can accommodate the wishes of stakeholders. Based on these models, it will be decided which plots of land are really needed for the climate change adaptation measures. Then the project manager can reach out to the landowner and see whether the land may be bought or other forms of agreements may be found (Interviews 2017). 


\section{Finding Agreements with Private Landowners or Users: Available Instruments}

Governmental authorities have a number of instruments at their disposal to find agreements with private landowners or users, either in the form of acquiring privately owned land or by convincing private users or landowners to cooperate.

\section{Communicative Instruments-Starting the Conversation with Private Landowners and Users}

Getting into contact with private landowners and users and talking about the ideas was the basis of this project. It was necessary to make contact with private landowners or landusers early on as the gauging network needed to be extended to collect the necessary scientific data. These gauging units are placed on private land. Obviously, the owners wanted to know why gauging units were placed in their gardens; therefore they were informed about the preliminary plans. Already in 2013, a number of so-called explorative kitchen table talks had been conducted with about 85 private stakeholders from the area. Stakeholders appeared to experience these talks rather positively. The talks generated trust, and people felt taken seriously as they were ensured that their knowledge and input would be considered. The stakeholders thought that this approach would facilitate collaborative thinking, where a lot of different perspectives would be considered and old paradigms could be overcome (Landschapsnetwerk Brummen 2013). According to an internal background report of the representative of the former DLG (Dienst Landelijk Gebied), a majority of the local people were enthusiastic about the project and the idea (Interviews 2017).

Back then the talks were conducted by the former DLG (Dienst Landelijk Gebied), which was part of the province. This governmental authority supported the development of rural areas. The main tasks included acquiring lands, reorganizing them, advising on their management and transferring them to area managers or individual farmers. In 2015, the DLG was closed, which was experienced as a great loss. Other individuals from other governmental authorities had to take over the conversations with the stakeholders, which caused delay and made the negotiations with stakeholders more difficult (Interviews 2017).

Nowadays, a presentative of the regional water authority has taken up the talks again. He has talked with 40-50 people during the last two years (2016-2017). The governmental representatives stress that they need and want the input of the local stakeholders. They want to understand citizens' problems, fears and wishes. By posing the right questions, governmental authorities can understand why citizens are doubtful, where particular knowledge or insights are missing. That enables them to develop solutions that also consider the citizens' position. It is possible to stimulate citizens and develop links to their own interests. Additionally, they set up a website to inform about the progress of the project. The website is regularly updated so that 
citizens can see the progress. Besides these kitchen table talks, they also organised information evenings where they present their ideas. In cases where farmers have no interest in contacting the representative of the regional water authority, the latter tries to establish the contact through an external person, for example via the LTO (an interest group representing the farmer sector), natuurmonumenten or a real-estate broker in the area (Interviews 2017).

When it comes to cooperation, governmental representatives acknowledge that, generally, the individual farmer has little interest in the overall aim of the project. The farmers' focus is mostly on their business and whether certain measures may influence its profitability. According to the respondents, the key skill for an area manager consists in thinking of synergies and how the project may benefit farmers. As one of the respondents pointed out, the area manager needs to be able to find solutions to these problems, s/he needs to have a lot of alternative options in the back of their head, and s/he needs to see synergies between different measures. "You can never say that you can do it. But you can propose to accommodate his/her [the landowners] wishes. [...] You have to give people time to think about this" (Interviews 2017).

\section{Coercive Instruments}

A coercive instrument (stick) would be land expropriation. Many countries have their own set of rules for expropriation for the use of private land for public goals. In general, the Dutch government can oblige private owners to give up their land when there is a clear public interest involved (article 1 Expropriation Act). Examples of such interests can be found in FRM (e.g., in case of dike relocations or creating space for the river like the Hedwige Polder) and also related to projects and plans formalized in land use planning, for example, a new land use designated for creating a housing area or a nature conservation area. The expropriation must be seen as the last resort (ultimum remedium) and other remedies must be tried first, such as a fair negotiation on the transfer of the land (amicable acquisition, minnelijke schikking, article 17 Expropriation Act).

When government starts negotiating to use private land for public goals, expropriation functions mostly as the big stick in the process. Negotiating a deal is more attractive than expropriation for the landowner; as the first case offers a possibility of exchanging land (land consolidation; ruilverkaveling) plus financial compensation while expropriation only leads to financial compensation (Holtslag-Broekhof 2016). The recent investigation of Sanne Holtslag-Broekhof (2016) demonstrates that the expropriation procedure is not a uniform or set case: in many cases the compensation after a court case is higher than the initial offer of the governmental authority involved. Several conditions are connected to the expropriation procedure; for example, expropriation is not legitimate if the landowner can realize the requested provision himor herself on private land (zelfrealisatierecht). Holtslag-Broekhof (2016) concludes that the deterrence that radiates from the Expropriation Act is working well in the 
Netherlands, considering the small number of court cases. In most instances, the negotiation leads to a voluntary transfer of land, although she also states that most landowners experience the threat with the big stick as very negative. We might perhaps add that this applies to all parties involved. Most water managers will not be happily involved in a process that might end in an expropriation procedure. According to the interviews, respondents normally tried to avoid confrontations with the landowners and tried to reach out for consensual solutions. This might also be as nature conservation and climate adaptation is not a strong case of public interest.

All in all, expropriation is often very difficult and not the preferred solution for negotiating partners and governmental officials. More differentiated regulations guide expropriation. Firstly, every province has its own provincial regulations that define when land may be expropriated, for example, when $90 \%$ of the plots of land are available for a project and only $10 \%$ are missing. If the owner is not willing to sell, his/her land may be expropriated. In practice, this is hardly ever applied. Secondly, provinces can expropriate land in the context of Natura 2000. However, within the Oekense Beek project, only some smaller plots are Natura 2000 designated areas. If landowners are not willing to change the designation of their land into nature, or do not agree with this change, their land can be expropriated on a relatively short time horizon. Regional water authorities may expropriate land in the context of PAS (Programma Aanpak Stikstof) measures. This programme finances measures to reduce nitrogen concentration in the soil. However, there are only two areas where PAS measures may be implemented in this project. The process of expropriation through PAS has to be developed and can take up to four years. However, it appears that in this project PAS expropriation is not viable (Interviews 2017).

Another coercive instrument would be stipulating particular requirements on landowners or leaseholders. The possibilities for governmental authorities to apply this approach are limited. Changing the existing designations of land would be connected to compensation demands. Some farmers also lease land from the municipalities or natuurmonumenten. For example, the municipality of Zutphen owns around 40 hectares of land, which is leased to a farmer. The farmer owns extensive livestock and is not particularly interested in alternative measures. The municipality of Zutphen would like to support the project but also has to listen to the interests of their leaseholder (Interviews 2017). Natuurmonumenten, in contrast, aims to actively promote sustainable farming. Therefore, they have established particular requirements that leasing farmers need to fulfil, for example, they are prohibited from using pesticides and must comply with any prescribed grazing density (based on e-mail contact with natuurmonumenten). Additionally, the farmers have to follow courses on nature conservation management and entrepreneurship ('Natuurbeheer en Ondernemerschap') to receive a certificate by 2021. Here farmers learn how to combine farming activities with nature development and at the same time develop new business models. The aim is that farmers increasingly consider the quality of the soil and the water and take measures to improve it (Natuurmonumenten 2017; Kloen 2015). The schooling activities may be considered a communicative instrument (sermons). 


\section{Financial Instruments}

The main instruments used for dealing with landowners and users are financial incentives (carrots), particularly buying land and/or exchanging land. The province bought small plots of land in the context of the Dutch Nature Network (NNN, Nederlandse Natuur Network). The NNN is a fund provided by the national government that provinces can use to buy land in order to increase the connectivity of ecosystems. The province could already implement measures in these areas. However, as at the moment it is not yet clear which measures are feasible with regard to the water system, they are not yet implementing measures. At the moment, one problem with buying land is the price. The price expectations between the province and the seller do not always align. Another possibility is exchanging land. At the beginning of such a project, the province looked around in the area to find farmers with a lot of land who would like to leave farming, for example, because they have no heir. The province bought some farms and their land. This land could be used for exchange. One provincial interviewee described it as follows: "Some farmers agree to give their land for the project, but they want to have other land in return, land with better soil quality and at a better location, otherwise they would accept money for compensation. In general, the most agreements with farmers can be made based on exchanging land or buying land" (Interviews 2017).

Another financial instrument is compensation. A compensation regulation provides for damages caused by wet conditions; in this case, the province and the regional water authority agreed to share the costs to farmers in the form of lost profit. But this compensation regulation is hardly used. Farmers do not favour this instrument either as it poses too high a risk of uncertainty to their business. However, a representative from the water authority pointed out that it could be combined with flexible solutions, for example, allowing farmers to operate the drainage apparatus. When the farmer wants to use his land, he can operate the drainage, and the wet soil gets drier and workable. At the moment, farmers are not in favour of this approach. One farmer, who is on the administrative board of LTO, thinks about trying this approach on his land as a pilot study (Interviews 2017).

Furthermore, subsidies or payment for particular services offer further financial incentives. In the context of funding programmes such as "Zoetwater Oost Nederland", "Delta Programme Agricultural Waters" or "Bodem en ondergrond" (Soil and Subsoil, a provincial program that aims to improve the soil quality), farmers or private landowners receive payment for cultivating and managing particular vegetation on their lands, such as grassland or alluvial forest. However, as one respondent described, they only receive a subsidy of $70 \%$. Therefore these measures do not always offer a real incentive to a farmer whose fields are cultivated and have no problems with water. Nevertheless, within the project area are also landowners who bought land from the province that was re-designated as nature. They receive money for managing this land. It seems important to give every landowner the same chances. A neighbouring landowner was not offered the possibility to deliver a nature management service in the first round. Now the owner's land is needed for the project, 
but his/her will to cooperate is limited as s/he was ignored the first time (Interviews 2017).

The municipality of Brummen established cooperation with a local farmer. They want to increase the water infiltration capacity of the soil by increasing the concentration of organic substances. Therefore they use the municipal organic garbage, process it and distribute in the farmer's field. For the municipality, this is more cost-efficient than transporting the garbage across long distances to burn it for biogas production, and the farmer gets paid for this service. As the soil quality is also improved, a representative called it a "win-win-win situation". Besides governmental authorities, Natuurmonumenten pays farmers for nature management activities. Some discussion has arisen on how to frame these financial incentives. The municipality of Brummen and other actors talk increasingly about "farmers receiving payment for delivering a service" instead of subsidies or compensation. A representative of the municipality explained that "services describe a clear agreement between actors with rights and responsibilities. It is a real business where taxes have to be paid" (Interviews 2017).

\section{Problem: Support Is Declining}

Nowadays stakeholders appear to be less enthusiastic about the project than they were at the beginning in 2013. During information evenings, experts were played against each other and statements were contorted. People may be less enthusiastic for several reasons. Due to the disbandment of DLG, a few years have passed since stakeholders have received any further information about the project. Another issue is mistrust against the government. If governmental officials come to them and talk about PAS measures, they need to mention that expropriation is a possibility. This scares many farmers. Furthermore, some citizens, particularly farmers, feel that the approach of the government is not very consistent. They argue that, decades ago, their family had to give up land to straighten streams, and, presently the government wants land to restore a meandering structure. Related to this, if there are amendments on the plan, one interviewee pointed out that stakeholders pose questions such as "now, what do you actually want? Do you actually know what you are doing?" These issues make the collaboration with private landowners additionally difficult (Interviews 2017).

\section{Reflecting on Challenges of Integrated, Collaborative Projects}

The successful implementation of climate change adaptation measures, particularly to address flooding, along the Oekense Beek is dependent on the collaboration with private landowners and users. Governmental authorities have several policy instruments at their disposal that may help them find agreements with private landowners. 
However, most agreements need to be found on a voluntary base with financial incentives. The governmental actors do not have many coercive instruments at their disposal. "Talking to people" is one of the essentials of this project as one respondent pointed out. Therefore it is necessary to consider the different interests and find compromise. One representative summarized it as follows: "We [citizens] must be able to live comfortably, but we [farmer] must also be able to make money. Compromise and poldering [Dutch cooperation approach based on compromise and consensus]."

However, this also leads to a number of challenges or dilemmas for implementing such an integrated and collaborative climate change adaptation project:

- Climate change adaptation is not perceived as an urgent issue by all of the stakeholders. Particularly, in this project, the lack of buffer capacity and the corresponding low groundwater level of the area is actually beneficial for farming activities as the fields are not too wet.

- The long duration of developing such a collaborative project and the iterative adjustment of the project plan due to new stakeholder interests make it difficult to maintain the positive attitude. Stakeholders question the urgency of the project and competence of the governmental authorities, which decreases their own willingness to collaborate. It is also difficult for the governmental authorities, as they need to communicate uncertainties or amendments to the stakeholders.

- The competition of multiple land uses poses additional challenges as the interests and needs of various landowners and users need to be considered. Landowners and leaseholders have rights to cultivate their land. In practice, it turns out to be difficult to provide sufficient financial incentives for farmers to change their approach. At the moment, it appears that another business model or other synergies need to be found in combination with financial incentives. In contrast, nature organisations whose intrinsic interests align with the aim of the project are more inclined to implement measures. One may even speculate that they would have done so anyway if they had the financial means.

- The development of innovative synergies is not always supported and sometimes downright hindered by the existing institutional structures. For example, the use of organic garbage to raise the concentration of organic substances in the soil is difficult to implement, as the existing waste management regulations do not consider these synergies. The flexible exchange of land is also sometimes hindered by strict regulations.

- The establishment of voluntary agreements with private landowners is sometimes negatively influenced by the legal need to inform. For example, when governmental authorities approach landowners in the context of the PAS measures, they have to disclose that, legally, expropriation is a possibility even though the regulations may not apply to this specific project. This scares off the landowner and negatively influences his/her willingness to collaborate in the project.

- It further seems important to treat the various landowners equally; otherwise they may be uncooperative in the subsequent process of the project, as they feel mistreated. However, this may be difficult as landowners have divergent interests, which sometimes ask for tailor-made solutions. 
Acknowledgements Open access of this chapter is funded by COST Action No. CA16209 Natural flood retention on private land, LAND4FLOOD (www.land4flood.eu), supported by COST (European Cooperation in Science and Technology).

\section{References}

Ansell C, Gash A (2007) Collaborative governance in theory and practice. J Public Adm Res Theor 18(4):543-571

Arts B, Leroy P, Arts B (2006) Institutional dynamics in environmental governance. Springer, Dordrecht

Baird J, Plummer R, Bodin Ö (2016) Collaborative governance for climate change adaptation in Canada: experimenting with adaptive co-management. Reg Environ Change 16(3):747-758

Bemelmans-Videc ML, Rist RC, Vedung E (2010) Carrots, sticks and sermons: policy instruments and their evaluation. Comparative policy evaluation series, $\mathrm{p} 277$

Biesbroek GR, Dupuis J, Jordan A, Wellstead AM, Howlett M, Cairney P, Rayner J, Davidson D (2015) Opening up the black box of adaptation decision-making. Nat Clim Change 5(6):493-494

Collins K, Ison R (2009) Jumping off Arnstein's ladder: social learning as a new policy paradigm for climate change adaptation. Environ Policy Gov 19(6):358-373

Driessen PPJ, Dieperink C, Van Laerhoven F, Runhaar HAC, Vermeulen WJV (2012) Towards a conceptual framework for the study of shifts in modes of environmental governance - experiences from the Netherlands. Environ Policy 160:143-160

Duit A (2015) Resilience thinking: lessons for public administration. Public Adm 94(2):364-380

Holtslag-Broekhof S (2016) Private grond voor Publieke doelen. Uitgeverij BOXPress

Kaufmann M, Van Doorn-Hoekveld W, Gilissen HK, Van Rijswick M (2016) Drowning in safetyanalysing and evaluating flood risk governance in the Netherlands. STARFLOOD Consortium, Utrecht

Kloen H (2015) Van Pacht naar Partnerschap. Landwerk 3:5-9

Brummen Landschapsnetwerk (2013) Advies bij DLG-studie klimaatcorridor en verbindingszone Oekense beek, Brummen. LNB, Brummen

Natuurmonumenten (2017) Gemeenschappelijk landbouwbeleid. Available via DIALOG. https:// www.natuurmonumenten.nl/standpunten/gemeenschappelijk-landbouwbeleid. Accessed 18 Dec 2017

Olsson P, Gunderson LH, Carpenter SR, Ryan P, Lebel L, Folke C, Holling CS (2006) Shooting the rapids: navigating transitions to adaptive governance of social-ecological systems. Ecol Soc 11(1)

Gelderland Provincie (2012) Water shortage and climate adaptation in the Rhine Basin. Provincie Gelderland, Arnhem

Gelderland Provincie (2016) Beheerplan Natura 2000 58-Landgoederen Brummen. Provincie Gelderland, Arnhem

Sjöstedt M (2015) Resilience revisited: taking institutional theory seriously. Ecol Soc 20(4)

Stroming (2013) A green Rhine corridor. Future proofing Western Europe's largest river for people, nature and the economy

Termeer CJAM, Dewulf A, Breeman G (2013) Climate change governance. In: Knieling J, Leal Filho W (eds) Climate change governance. Springer, Berlin, Heidelberg, pp 27-39

Wise RM, Fazey I, Stafford Smith M, Park SE, Eakin HC, Archer Van Garderen ERM, Campbell B (2014) Reconceptualising adaptation to climate change as part of pathways of change and response. Glob Environ Change 28:325-336 
Maria Kaufmann is an Assistant Professor in Environmental Governance at the Radboud University in Nijmegen, The Netherlands. Maria has a multidisciplinary background holding an MSc degree in Environmental Sciences and a Ph.D. degree in Management Sciences. Maria's research focuses on examining environment-society interactions in the context of climate adaptation, particularly flood risk governance. She is interested in analyzing institutional dynamics and evaluating governance arrangements in terms of environmental justice.

Mark Wiering is Associate-Professor in Environmental Governance and Politics at Radboud University in Nijmegen, The Netherlands. He is interested in societal transformations in light of sustainability and the role environmental governance therein. His domains are, more specifically, the dynamics of governance in FRM and water quality management and the dynamics related to grass roots movements in renewable energy.

Open Access This chapter is licensed under the terms of the Creative Commons Attribution 4.0 International License (http://creativecommons.org/licenses/by/4.0/), which permits use, sharing, adaptation, distribution and reproduction in any medium or format, as long as you give appropriate credit to the original author(s) and the source, provide a link to the Creative Commons license and indicate if changes were made.

The images or other third party material in this chapter are included in the chapter's Creative Commons license, unless indicated otherwise in a credit line to the material. If material is not included in the chapter's Creative Commons license and your intended use is not permitted by statutory regulation or exceeds the permitted use, you will need to obtain permission directly from the copyright holder. 